\title{
Analisis Reaksi Pasar Terhadap Perubahan Peraturan Kemenperin Nomor 31/M-Ind/Per/8/2017 Pada Perusahaan Manufaktur di BEI
}

\author{
Erving Anggiatma Napitupulu ${ }^{1}$ \\ Gerianta Wirawan Yasa ${ }^{2}$ \\ ${ }^{1}$ Fakultas Ekonomi dan Bisnis Universitas Udayana (Unud), Bali, Indonesia \\ email: giasurvival@yahoo.co.id/Tlp: 087824503668 \\ ${ }^{2}$ Fakultas Ekonomi dan Bisnis Universitas Udayana (Unud), Bali, Indonesia
}

\begin{abstract}
ABSTRAK
Penelitian ini bertujuan untuk mengetahui reaksi pasar terhadap perubahan peraturan kemenperin. Metodologi penelitian yang digunakan adalah event study untuk menguji kandungan informasi (information content) dari suatu pengumuman. Subjek penelitian ini adalah perusahaan manufaktur yang terdaftar di Bursa Efek Indonesia, pemilihan sampel dilakukan secara purposive sampling, yaitu populasi yang memenuhi kriteria tertentu dengan tujuan untuk mendapatkan sampel yang representatif sesuai dengan kriteria yang ditentukan. Teknik analisis data yang digunakan adalah uji one sample t test pada hipotesis 1 dan uji Mann Whitney untuk hipotesis 2. Hasil pengujian reaksi pasar terhadap seluruh sampel menunjukkan terdapat reaksi terhadap perubahan peraturan Kemenperin NOMOR 31/M-IND/PER/8/2017 pada perusahaan manufaktur pada hari ketiga sebelum pengumuman perubahan peraturan dan hari kedua setelah pengumuman perubahan peraturan. Terdapat perbedaan reaksi antara perusahaan manufaktur dan perusahaan non manufaktur terhadap perubahan peraturan Kemenperin NOMOR 31/M-IND/PER/8/2017 pada periode hari ketiga sebelum pengumuman perubahan peraturan dan hari kedua setelah pengumuman perubahan peraturan.
\end{abstract}

Kata kunci: reaksi pasar, abnormal return, kandungan informasi

\begin{abstract}
This study aims to determine the market reaction to changes in regulations in the Ministry of Industry. The methodology used is event study to examine the information content of an announcement. The subject of this research is a manufacturing company listed on the Indonesia Stock Exchange, the sample selection choosen by purposive sampling. The data analysis technique used was the one sample t test on hypothesis 1 and the Mann Whitney test for hypothesis 2. The test results of the market reaction showed a reaction to changes in the Ministry of Industry regulation on the company manufacturing on the third day before the announcement of regulatory changes and the second day after the announcement of regulatory changes. There are differences in the reaction between manufacturing companies and non-manufacturing companies in the third day period before the announcement of regulatory changes and the second day after the announcement of regulatory changes.

Keywords: market reaction, abnormal return, information content
\end{abstract}

\section{PENDAHULUAN}

Perkembangan pasar modal di indonesia semakin pesat, hal ini terlihat dari semakin banyak jumlah saham yang diperdagangkan dan semakin tingginya volume perdagangan saham di bursa efek indonesia (bei). salah satu alternatif 
pilihan investasi yang dapat menghasilkan keuntungan optimal bagi investor adalah pasar modal.

Peran pasar modal dalam meningkatkan perekonomian sangat strategis karena pasar modal adalah sumber dana alternatif bagi perusahaan - perusahaan. Salah satu pembentuk Gross Domestic Bruto (GDP) secara nasional adalah perusahaan - perusahaan yang terdaftar di BEI. Semakin berkembangnya pasar modal, maka kemungkinan meningkatnya GDP juga akan semakin besar. Dua fungsi strategis pasar modal adalah fungsi ekonomi dan fungsi keuangan. Fungsi ekonomi dalam pasar modal adalah menyalurkan dana dari pihak yang mempunyai dana lebih (investor) kepada pihak yang memerlukan dana (issuer) .

Fungsi keuangan pasar modal adalah memberikan kesempatan investor kesempatan untuk memperoleh imbalan (return) sebagai hasil investasinya. Informasi yang diperlukan oleh investor adalah informasi yang bersifat teknikal dan fundamental. Informasi yang berasal dari eksternal perusahaan adalah informasi yang bersifat teknikal, sedangkan informasi yang berasal dari internal perusahaan adalah informasi yang bersifat fundamental. Hal yang sangat di diperhatikan investor dalam melakukan investasi adalah laba perusahaan. Jika laba perusahaan meningkat, harga saham kemungkinan meningkat dan return bisa meningkta. Hal yang diperlukan untuk memprediksi return dan risiko dalam berinvestasi adalah kedua informasi tersebut.

Besarnya return yang akan diperoleh sangat mempengaruhi keputusan investor dalm berinvestasi. return dibedakan menjadi dua yaitu return realisasi dan return ekspektasi (Hartono, 2015 : 263). Saat melakukan investasi, investor 
selalu dihadapkan pada ketidakpastian (uncertainty) apakah return yang diperoleh lebih tinggi dibandingkan dengan risiko yang dihadapi. Semakin tinggi risiko yang diambil, semakin besar juga peluang untuk mendapatkan return yang tinggi (high risk high return, low risk low return). Ada dua jenis return yang bisa diterima investor di pasar modal, yaitu current income dan capital gain/loss Current income adalah keuntungan yang diterima secara periodik seperti dividen sedangkan capital gain/loss merupakan kenaikan/penurunan harga saham periode sekarang dengan periode sebelumnya.

Yusuf (2009), menemukan bukti bahwa terdapat perbedaan yang signifikan antara return saham sebelum dengan sesudah pengumuman right issue. Sugeng (2011), menemukan bukti bahwa dari hasil penelitian pengumuman informasi dividen kas, baik itu dividen naik maupun turun dari saham - saham yang masuk LQ 45 menunjukkan bahwa investor tidak bereaksi terhadap informasi tersebut. Hal ini ditunjukkan dengan tidak adanya perbedaan yang signifikan secara statistik antara Average Abnormal Return (AAR) sebelum dan sesudah pengumuman dividen kas. Putri (2017), menemukan bukti bahwa peristiwa terbitnya PMK Tax Amnesty tidak memiliki pengaruh terhadap volume perdagangan, hal ini berarti bahwa peristiwa terbitnya PMK Tax Amnesty pada tanggal 18 Juli 2016 tidak membuat investor bereaksi. Endah dan Widanaputra (2016) menemukan bukti bahwa tidak terdapat beda return sebelum dan sesudah release maupun diterapkannya peraturan pelarangan minuman beralkohol.

Salah satu instrumen hukum yang diperlukan dalam pelaksanaan perundang-undangan adala peraturan menteri . Seorang menteri dapat 
mengeluarkan suatu peraturan untuk mempermudah pelaksanaan administratif atau untuk kepentingan prosedur lainnya. Pasal 8 Ayat (1) yang menyatakan bahwa Jenis Peraturan Perundang-undangan berlaku secara sah atas peraturan yang dikeluarkan oleh Majelis Permusyawaratan Rakyat dan Dewan Perwakilan Rakyat, Dewan Perwakilan Daerah, Mahkamah Agung, Mahkamah Konstitusi, Badan Pemeriksa Keuangan, Bank Indonesia, Menteri, kepala badan, lembaga, atau komisi yang setingkat yang dibentuk oleh undang-undang atau pemerintah atas perintah undang-undang, dewan perwakilan rakyat daerah provinsi, gubernur, dewan perwakilan rakyat daerah kabupaten/kota, bupati/walikota, kepala desa atau yang setingkat. Hal ini berarti menteri memiliki kedudukan yang sah dalam kaitannya terhadap pembuatan peraturan yang berlaku.

Pada tanggal 3 Agustus 2017 Kemenperin menerbitkan peraturan baru dengan NOMOR 31/M-IND/PER/8/2017 tentang perubahan ketiga atas Kementerian Perindustrian NOMOR 19/M-IND/PER/2/2010 tentang daftar mesin, barang, dan bahan produksi dalam negeri untuk pembangunan atau pengembangan industri dalam rangka penanaman modal. Perubahan tersebut adalah perubahan mengenai harmonized system. Harmonized system adalah suatu daftar penggolongan barang yang dibuat secara sistematis dengan tujuan mempermudah penarifan, transaksi perdagangan, pengangkutan dan statistik yang telah diperbaiki dari sistem klasifikasi sebelumnya. Saat ini pengklasifikasian barang di Indonesia didasarkan kepada Harmonized System dan dituangkan ke dalam suatu daftar tarif yang disebut Buku Tarif Bea Masuk Indonesia (BTBMI). 
Jika harmonized system berubah, maka berdampak pada pengklasifikasian barang yang akan berpengaruh terhadap Bea Masuk Umum/Most Favoured Nation (MFN), Bea Masuk Free Trade Agreement (FTA), Bea Keluar, BMAD (Bea Masuk Anti Dumping) dan BMTP (Bea Masuk Tindak Pengaman), Pajak Dalam Rangka Impor (PPN, PPnBM dan PPh Pasal 22), Dokumen perijinan dalam rangka larangan dan pembatasan impor/ekspor. Hal tersebut akan mempengaruhi laba/rugi perusahaan manufaktur. Selain itu perubahan Buku Tarif Pabean Indonesia (BTKI) juga berdampak pada Penyesuaian modul Pemberitahuan Impor Barang (PIB), Pemberitahuan Ekspor Barang (PEB) dan pemberitahuan pabean terkait lainnya, Aturan lartas pada Kementerian dan Lembaga, Penyesuaian IT Inventory atau aplikasi sejenis di perusahaan. Adanya perubahan peraturan kempenperin tersebut, maka akan berpengaruh terdapat biaya perusahaan manufaktur dan akan mempengaruhi laba/rugi perusahaan manufaktur karena peraturan tersebut adalah peraturan yang bersifat sektoral dan seharusnya tidak mempengaruhi sektor lain.

Berdasarkan hal-hal tersebut, maka penelitian ini bertujuan untuk mengetahui apakah terdapat reaksi pasar terhadap Perubahan Peraturan Kemenperin pada perusahaan manufaktur di BEI dan untuk mengetahui apakah terdapat perbedaan reaksi pasar antara perusahaan manufaktur dan non manufaktur terhadap Perubahan Peraturan Kemenperin pada perusahaan manufaktur di BEI.

Teori efisiensi pasar adalah proposisi yang menyatakan harga saham saat ini merefleksikan secara penuh informasi yang tersedia mengenai nilai perusahaan 
perusahaan dan tidak ada cara lain untuk menghasilkan keuntungan melebihi pasar secara keseluruhan dengan menggunakan informasi tersebut. Teori ini membahas salah satu isu yang sangat fundamental pada manajemen keuangan mengenai fluktuasi harga di pasar modal dan bagaimana positioning fluktuasi tersebut. Kedua isu ini memiliki implikasi penting baik itu untuk investor maupun manajemen keuangan.

Pasar efisien yang ditinjau dari sudut informasi saja disebut dengan efisiensi pasar secara informasi (informationally efficient market). Pasar efisien yang ditinjau dari sudut kecanggihan pelaku pasar dalam mengambil keputusan berdasarkan informasi yang tersedia disebut dengan efisiensi pasar secara keputusan (decisionally efficient market).

Return merupakan hasil yang diperoleh dari investasi (Hartono, 2015 :263). Return saham terdiri dari: Yield, yaitu keuntungan yang dibayarkan secara periodik, biasanya dalam bentuk dividen. Capital gain, atau capital loss, yaitu kenaikan/penurunan harga saham pada saat investor membeli dengan harga saham pada saat investor menjual saham tersebut. Capital gain jika harga saham pada akhir periode mengalami kenaikan dari harga awalnya, sedangkan capital loss, harga saham pada akhir periode mengalami penurunan dari harga awalnya .

Risiko adalah kemungkinan-kemungkinan bahwa suatu pengembalian akan berbeda dari tingkat pengembalian yang diharapkan. Ada dua tipe resiko, yaitu Risiko sistematik (Systematic Risk) dan Risiko non-sistematik (NonSystematic risk). Ada 3 jenis investor, yaitu risk taker, risk neutral, dan risk averse. Risk taker adalah kecendrungan investor yang memilih taruhan yang fair. 
Risk neutral adalah kecendrungan investor yang bersikap indifference terhadap taruhan yang fair. Risk averse adalah kecendrungan investor akan menolak taruhan yang fair. Kecendrungan tersebut menyebabkan investor mempunyai cara pandang yang berbeda dalam melihat suatu portofolio.

Abnormal return dapat diterjemahkan sebagai return taknormal atau return takwajar Hartono (2015 : 624). Abnormal return terjadi karena ada informasi baru atau peristiwa baru yang mengubah nilai perusahaan dan direaksi oleh investor dalam bentuk kenaikan atau penurunan saham. Selisih return akan positif jika return realisasian lebih besar dari return ekspektasian atau return yang dihitung. Sedangkan return akan negatif jika return realisasian lebih kecil dari return ekspektasian atau return yang dihitung. Abnormal return dapat terjadi karena adanya kejadian-kejadian tertentu, misalnya hari libur nasional, awal bulan, awal tahun, suasana politik yang tidak menentu, kejadian-kejadian yang luar biasa, stock split, penawaran perdana saham, dan lain-lain

Penelitian ini akan melihat abnormal return yang terjadi selama waktu pengamatan 7 hari dengan menggunakan alat statistik untuk melihat reaksi pasar dan melihat apakah terdapat abnormal return selama waktu pengujian dengan tingkat signifikansi 5\%. Jika pengumuman tersebut mengandung informasi, maka diharapkan pasar akan bereaksi pada waktu pengumuman tersebut diterima pasar. Reaksi pasar akan tercermin dari perubahan harga saham perusahaan yang tercatat di BEI. Reaksi ini akan diukur menggunakan abnormal return sebagai tolok ukurnya. Berdasarkan hal tersebut, maka suatu pengumuman yang memiliki kandungan informasi akan memberikan abnormal return terhadap harga saham. 
Adanya perubahan harmonized system akan berpengaruh terhadap pengklasifikasian barang dan tarif barang yang akan berpengaruh terhadap biaya biaya perusahaan manufaktur. Dampak dari perubahan peraturan tersebut adalah rata-rata tarif BTKI 2017 naik menjadi 10,08\% dibandingkan rata - rata tarif BTKI tahun 2012 yang sebesar 8,81\%. Adanya pengaruh perubahan harmonized system yang berpegaruh terhadap biaya dan laba/rugi perusahaan manuaktur, maka seharusnya investor bereaksi terhadap perubahan peraturan tersebut. Beberapa penelitian sebelumnya yang menguji tentang pengaruh perubahan peraturan terhadap abnormal return dan mendapatkan hasil yang menunjukkan bahwa pasar bereaksi diantaranya: Wibowo (2017) menemukan bukti bahwa terdapat abnormal return positif yang signifikan di sekitar pengumuman Paket Kebijakan Ekonomi Tahap I Jokowi-JK dan Liogu dan Serang (2015) menemukan bukti bahwa adanya perbedaan pada abnormal return yang signifikan sebelum dan sesudah pengumuman kenaikan harga BBM pada tanggal 1 November 2014 atas saham LQ-45. Berdasarkan hal tersebut, maka hipotesis penelitian ini adalah :

$\mathrm{H}_{1}$ : Terdapat reaksi pasar terhadap peristiwa pengumuman perubahan peraturan Kemenperin pada perusahaan manufaktur di Bursa Efek Indonesia.

Perubahan peraturan ini akan mempengaruhi laba rugi khusus perusahaan manufaktur karena perubahan peraturan ini tentang perubahan ketiga atas Kementerian Perindustrian NOMOR 19/M-IND/PER/2/2010 tentang daftar mesin, barang, dan bahan produksi dalam negeri untuk pembangunan atau pengembangan industri dalam rangka penanaman modal. Perubahan tersebut adalah perubahan mengenai harmonized system. Jika harmonized system berubah, 
maka berdampak pada pengklasifikasian barang yang akan berpengaruh terhadap Bea Masuk Umum/Most Favoured Nation (MFN), Dokumen perijinan dalam rangka larangan dan pembatasan impor/ekspor, Bea Keluar, Bea Masuk Free Trade Agreement (FTA), Pajak Dalam Rangka Impor (PPN, PPnBM dan PPh Pasal 22), BMAD (Bea Masuk Anti Dumping) dan BMTP (Bea Masuk Tindak Pengaman) dan seharusnya tidak mempengaruhi laba rugi perusahaan sektoral yang lain, sehingga reaksi pasar seharusnya hanya terjadi terhadap perusahaan manufaktur. Berdasarkan hal tersebut, hipotesis kedua penelitian ini adalah :

$\mathrm{H}_{2}$ : Terdapat perbedaan reaksi pasar terhadap peristiwa pengumuman perubahan peraturan Kemenperin perusahaan manufaktur dengan perusahaan non manufaktur.

Berdasarkan uraian tersebut, maka kerangka konseptual dapat digambarkan pada Gambar 1 :

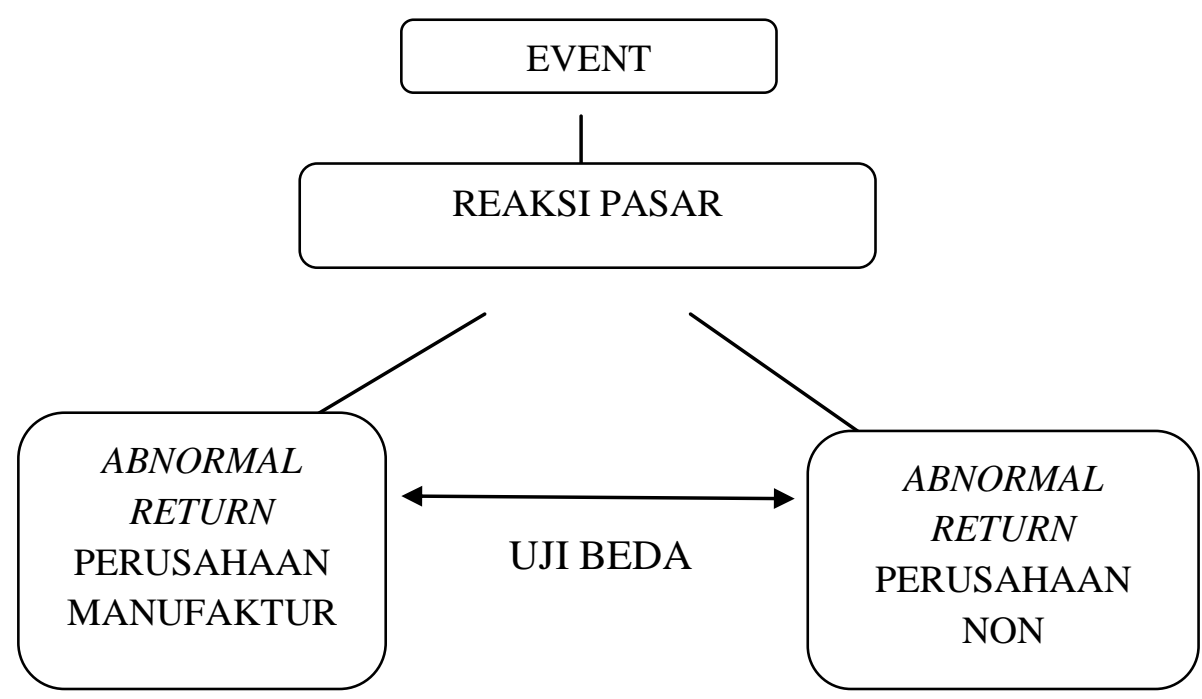

Gambar 1 Kerangka Konseptual

\section{METODE PENELITIAN}


Penelitian ini adalah sebuah event study dengan menggunakan pendekatan kuantitatif. Pendekatan kuantitatif dalam penelitian ini adalah mengukur reaksi pasar menggunakan abnormal return. Event yang diteliti adalah peristiwa perubahan peraturan kemenperin. Objek penelitian ini adalah abnormal return perusahaan manufaktur dan non manufaktur yang go-public di BEI.

Reaksi pasar modal terhadap peristiwa perubahan peraturan Kemenperin dalam penelitian ini diukur dari abnormal return. Periode penelitian yang digunakan adalah periode amatan selama 7 hari yaitu 3 hari sebelum peristiwa ( $\mathrm{t}-3$ ), 1 hari saat peristiwa (event date $\mathrm{t}=0$ ) dan 3 hari sesudah tanggal peristiwa $(\mathrm{t}+3)$. Penelitian ini menggunakan periode waktu singkat selama 7 hari kerja Bursa Efek Indonesia (BEI) dengan pembagian: hari sebelum ( $\mathrm{t}-1$ sampai t-3), event date $(\mathrm{t}=0)$, dan hari setelah $(\mathrm{t}+1$ sampai $\mathrm{t}+3)$. Periode waktu singkat 7 hari digunakan dengan asumsi bahwa memadai dan cukup bagi pelaku pasar dalam merespon perubahan peraturan Kemenperin ini. Sebuah event window period yang terlalu panjang akan menyerap dampak peristiwa ekonomi, non ekonomi dan politik lainnya yang tidak termasuk dalam penelitian, sedangkan jendela yang terlalu pendek juga tidak dapat menganalisis efek dari suatu peristiwa dengan baik. Perbedaan reaksi pasar modal perusahaan manufaktur dan non manufaktur yang diukur dari abnormal return. Periode estimasi yang digunakan dalam penelitian ini adalah periode estimasi selama 100 hari, yaitu dari $t_{-4}$ sampai $t_{-103}$.

Reaksi pasar modal dan perbedaannya diukur dengan menggunakan abnormal return. Abnormal return terjadi karena adanya sebuah pengumuman terkait dengan perubahan peraturan kemenperin yang mengandung informasi yang 
relevan dan informasi tersebut diterima oleh emiten untuk pengambilan keputusan dalam investasi. Respon yang dilakukan oleh emiten tersebut dapat menyebabkan adanya abnormal return baik positif maupun negatif. Abnormal return dapat diukur dengan cara membandingkan return ekspektasian dengan return realisasian dalam bentuk ukuran presentase. Model yang digunakan adalah mean adjust model dengan mengurangkan return yang terjadi untuk masing-masing sekuritas pada hari yang sama. Alasan penggunaan mean adjust model pada penelitian ini karena perusahaan manufaktur merupakan perusahaan sektoral sehingga tidak bisa menggunakan indeks pasar sebagai cara mengestimasi return ekspektasian suatu sekuritas sehingga harus menghitung return ekspektasian setiap perusahaan.

Populasi untuk penelitian ini adalah saham-saham perusahaan-perusahaan yang ada di Bursa Efek Indonesia. Metode pengumpulan data yang digunakan adalah purposive sampling. Purposive sampling adalah teknik pengambilan sampel secara tidak acak yang informasinya diperoleh menggunakan pertimbangan tertentu yaitu dengan pertimbangan bahwa sampel merupakan perusahaan manufaktur dan non manufaktur yang terdaftar di BEI yang tidak melakukan corporate action. Untuk perusahaan non manufaktur akan dilihat total asset dan dibandingkan dengan total asset perusahaan manufaktur, jika total asset perusahaan non manufaktur tersebut setara dengan total asset perusahaan manufaktur, maka perusahaan non manufaktur tersebut dimasukkan sebagai sampel.

Jenis data untuk penelitian ini adalah data sekunder. Sumber data untuk penelitian ini adalah harga saham perusahaan manufaktur dan non manufaktur 
yang terdaftar BEI. Metode pengumpulan data untuk penelitian ini adalah metode observasi non partisipan. Metode observasi non partisipan adalah observasi yang dalam pelaksanaannya tidak melibatkan peneliti sebagai partisipasi atau kelompok yang diteliti.

Teknik analisis data yang digunakan dalam penelitian ini adalah one sample t test dan uji beda independent sampe t test jika data berdistribusi normal atau Mann - Whitney jika data tidak berdistribusi normal . One sample t test digunakan untuk melihat apakah terdapat reaksi pasar, sedangkan independent sample t test atau Mann - Whitney digunakan untuk menentukan apakah dua sample yang berhubungan memiliki nilai rata-rata yang berbeda, untuk penelitian ini untuk menguji abnormal return perusahaan manufaktur dan perusahaan non manufaktur.

\section{HASIL DAN PEMBAHASAN}

Kriteria pemilihan sampel dalam penelitian ini adalah perusahaan manufaktur dan non manufaktur yang total asetnya setara dan tidak melakukan corporate action. Sampel penelitian ini terdiri dari 111 perusahaan manufaktur dan 111 perusahaan non manufaktur. Berdasarkan kriteria pemilihan sampel tersebut, diperoleh sampel yang dapat dilihat pada Tabel .

Pengujian deskriptif dilakukan untuk mengetahui gambaran umum tentang sampel. Deskriptif sampel berupa nilai minimum, nilai maksimum, deviasi standar, dan rata-rata (mean). Nilai minimum adalah nilai yang terendah dari sebuah distribusi data dan nilai maksimum adalah nilai tertinggi dari sebuah distribusi data. Pengukuran rata-rata (mean) merupakan cara yang sering digunakan untuk mengukur nilai sentral dari sebuah distribusi data, sedangkan 
pengukuran keragaman (variasi) yang paling sering digunakan adalah deviasi standar.

Tabel 1.

Hasil Pemilihan Sampel

\begin{tabular}{clc}
\hline No & \multicolumn{1}{c}{ Kriteria } & Jumlah Perusahaan \\
\hline 1 & Perusahaan manufaktur yang terdaftar di BEI 2017 & 111 \\
2 & Perusahaan non manufaktur yang terdaftar di BEI 2017 & 457 \\
3 & Perusahaan non manufaktur yang asetnya tidak setara & $(338)$ \\
4 & Perusahaan yang melakukan corporate action & $(8)$ \\
\hline & Jumlah Sampel Akhir & 222 \\
\hline
\end{tabular}

Sumber: BEI 2017

Abnormal return disajikan dalam 3 hari sebelum, 1 hari saat, dan 3 hari setelah tanggal pengumuman. Tanggal pengumuman dalam penelitian ini adalah pada tanggal 3 Agustus 2017. Abnormal return dalam penelitian ini terdiri dari abnormal return perusahaan manufaktur dan perusahaan non manufaktur. Adapun statistik deskriptif terhadap abnormal return ditunjukkan pada Tabel 2.

Tabel 2.

Statistik Deskriptif Abnormal Return (Perusahaan Manufaktur)

\begin{tabular}{cccccc}
\hline & $\mathbf{N}$ & Minimum & Maksimum & Rata-rata & Deviasi standar \\
\hline T-3 & 111 & $-0,17$ & 0,10 & $-0,00$ & 0,04 \\
T-2 & 111 & $-0,08$ & 0,25 & $-0,00$ & 0,03 \\
T-1 & 111 & $-0,14$ & 0,10 & $-0,00$ & 0,02 \\
T 0 & 111 & $-0,19$ & 0,15 & $-0,00$ & 0,03 \\
T+1 & 111 & $-0,12$ & 0,24 & 0,00 & 0,04 \\
T+2 & 111 & $-0,14$ & 0,03 & $-0,01$ & 0,03 \\
T+3 & 111 & $-0,17$ & 0,26 & 0,00 & 0,04 \\
\hline
\end{tabular}

Sumber: Data diolah, 2018

Berdasarkan Tabel 2 didapatkan bahwa rata-rata abnormal return negatif terjadi pada 3 hari sebelum pengumuman, pada saat pengumuman dan hari kedua setelah pengumuman yang berarti return realisasian lebih kecil dibandingkan return ekspektasian, sedangkan hari pertama dan hari ketiga setelah pengumuman 
terjadi rata-rata abnormal return positif yang berarti return realisasian lebih besar dibandingkan return ekspektasian.

Berdasarkan Tabel 3 didapatkan bahwa rata-rata selama 7 hari perusahaan non manufaktur menghasilkan rata-rata abnormal return yang positif pada 3 hari sebelum pengumuman, hari pertama dan hari ketiga setelah pengumuman yang berarti bahwa return realisasian lebih besar dari return ekspektasian. Pada saat pengumuman dan hari kedua setelah pengumuman terdapat rata-rata abnormal return negatif yang berarti bahwa return realisasian lebih kecil dari return ekspektasian.

Tabel 3.

Statistik Deskriptif Abnormal Return (Perusahaan Non Manufaktur)

\begin{tabular}{cccccc}
\hline & N & Minimum & Maksimum & Rata-rata & Deviasi standar \\
\hline T-3 & 111 & $-0,08$ & 0,24 & 0,00 & 0,04 \\
T-2 & 111 & $-0,19$ & 0,35 & 0,00 & 0,04 \\
T-1 & 111 & $-0,08$ & 0,34 & 0,00 & 0,04 \\
T 0 & 111 & $-0,17$ & 0,27 & $-0,00$ & 0,04 \\
T+1 & 111 & $-0,06$ & 0,23 & 0,00 & 0,04 \\
T+2 & 111 & $-0,10$ & 0,10 & $-0,00$ & 0,02 \\
T+3 & 111 & $-0,11$ & 0,19 & 0,00 & 0,03 \\
Valid N (listwise) & 111 & & & & \\
Sumber: Data diolah, 2018 & & & & & \\
& & &
\end{tabular}

Smirnov. Data dianggap berdistribusi normal apabila nilai signifikansi dari uji Kolmogorov-Smirnov > 0,05. Hasil uji normalitas dapat dilihat pada Tabel 4.

Tabel 4. 


\section{Pengujian Normalitas Data Abnormal Return Perusahaan Manufaktur dan Perusahaan Non Manufaktur}

\begin{tabular}{ccc}
\hline Periode & $\begin{array}{c}\text { Perubahan peraturan baru dengan NOMOR 31/M-IND/PER/8/2017 tentang } \\
\text { daftar mesin, barang, dan bahan produksi dalam negeri untuk pembangunan } \\
\text { Jendela }\end{array}$ & $\begin{array}{c}\text { Signifikansi }(2-t a i l e d) \\
\text { Kauterangan }\end{array}$ \\
t-3 & 0,00 & Tidak Normal \\
t-2 & 0,00 & Tidak Normal \\
t-1 & 0,00 & Tidak Normal \\
t0 & 0,00 & Tidak Normal \\
t+1 & 0,00 & Tidak Normal \\
t+2 & 0,00 & Tidak Normal \\
t+3 & 0,00 & Tidak Normal \\
\hline
\end{tabular}

Sumber: Data diolah, 2018

Hasil pengujian normalitas abnormal return pada tabel. 4 terlihat bahwa sebelum, saat, dan setelah penerbitan perubahan peraturan Kemenperin NOMOR 31/M-IND/PER/8/2017 data berdistribusi tidak normal antara abnormal return perusahaan manufaktur dan perusahaan non manufaktur. Hal ini bisa dilihat dari nilai signifikansi kurang dari 0,05 selama periode pengamatan. Berdasarkan hasil yang di dapat, maka uji yang dilakukan untuk hipotesis 2 adalah uji Mann Whitney.

Pengujian hipotesis pertama dalam penelitian ini dilakukan dengan menggunakan one sample t test. Hipotesis pertama menguji apakah terdapat reaksi yang diukur dengan abnormal return yang signifikan di sekitar penerbitan perubahan peraturan Kemenperin NO. 31/M-IND/PER/8/2017. Cara mengetahui apakah terdapat reaksi atau tidak dengan membandingkan abnormal return dengan 0. Hasil uji one sample t test terhadap abnormal return pada Tabel 5.

Tabel. 5 
Hasil Uji One Sample t-test Abnormal Return (Perusahaan Manufaktur)

\begin{tabular}{cccc}
\hline $\begin{array}{c}\text { Periode } \\
\text { Jendela }\end{array}$ & $\begin{array}{c}\text { Signifikansi } \\
\text { (2-tailed })\end{array}$ & Rata-Rata & $\begin{array}{c}\text { Keterangan } \\
\text { Abnormal } \text { Return }\end{array}$ \\
\hline $\mathrm{t}-3$ & 0,03 & $-0,00$ & Signifikan \\
$\mathrm{t}-2$ & 0,71 & $-0,00$ & Tidak Signifikan \\
$\mathrm{t}-1$ & 0,46 & $-0,00$ & Tidak Signifikan \\
t0 & 0,16 & $-0,00$ & Tidak Signifikan \\
$\mathrm{t}+1$ & 0,37 & 0,00 & Tidak Signifikan \\
$\mathrm{t}+2$ & 0,00 & $-0,01$ & Signifikan \\
$\mathrm{t}+3$ & 0,68 & 0,00 & Tidak Signifikan \\
\hline Sumber: Data diolah, 2018 & & &
\end{tabular}

Sumber: Data diolah, 2018

Abnormal return dianggap signifikan jika sig (2-tailed) $\leq 0,05$ yang dapat diartikan juga terdapat reaksi pasar terhadap penerbitan perubahan peraturan Kemenperin NOMOR 31/M-IND/PER/8/2017, begitu juga sebaliknya. Hasil tabel 5 menunjukkan terdapat reaksi negatif pada periode 3 hari sebelum pengumuman, pada saat pengumuman dan hari kedua setelah pengumuman. Adanya reaksi pasar negatif yang signifikan pada periode hari ketiga sebelum pengumuman dan hari kedua setelah pengumuman menunjukkan bahwa peristiwa tersebut mengandung informasi, sedangkan pada periode hari pertama dan hari kedua sebelum pengumuman, pada saat pengumuman, hari pertama dan hari ketiga setelah pengumuman terdapat reaksi pasar yang tidak signifikan.

Hasil tabel 6 menunjukkan tidak terdapat reaksi yang signifikan pada periode 3 hari sebelum pengumuman, pada saat pengumuman dan 3 hari setelah pengumuman untuk perusahaan non manufaktur. Tidak adanya reaksi pasar signifikan pada periode 3 hari sebelum pengumuman, pada saat pengumuman dan 3 hari setelah pengumuman perubahan peraturan Kemenperin NOMOR 31/MIND/PER/8/2017, menunjukkan bahwa peristiwa tersebut tidak mempengaruhi reaksi investor terhadap perusahaan non manufaktur. 
Tabel. 6

Hasil Uji One Sample t-test Abnormal Return (Perusahaan Non Manufaktur)

\begin{tabular}{cccc}
\hline $\begin{array}{c}\text { Periode } \\
\text { Jendela }\end{array}$ & $\begin{array}{c}\text { Signifikansi } \\
(\mathbf{2}-\text { tailed })\end{array}$ & Rata-rata & $\begin{array}{c}\text { Keterangan } \\
\text { Abnormal Return }\end{array}$ \\
\hline $\mathrm{t}-3$ & 0,24 & 0,00 & Tidak Signifikan \\
$\mathrm{t}-2$ & 0,89 & 0,00 & Tidak Signifikan \\
$\mathrm{t}-1$ & 0,26 & 0,00 & Tidak Signifikan \\
$\mathrm{t} 0$ & 0,85 & $-0,00$ & Tidak Signifikan \\
$\mathrm{t}+1$ & 0,11 & 0,00 & Tidak Signifikan \\
$\mathrm{t}+2$ & 0,55 & $-0,00$ & Tidak Signifikan \\
$\mathrm{t}+3$ & 0,34 & 0,00 & Tidak Signifikan \\
\hline Sumber: Data diolah, 2018 & & &
\end{tabular}

Pengujian hipotesis kedua dalam penelitian ini dilakukan dengan menggunakan uji Mann Whitney. Uji tersebut dipilih karena hasil uji distribusi data abnormal return perusahaan manufaktur dan non manufaktur hasil yang didapat adalah data tidak berdistribusi normal. Data yang diuji adalah abnormal return perusahaan manufaktur dan perusahaan manufaktur pada event date. Hasil uji Mann Whitney ditampilkan dalam Tabel 7.

Tabel. 7

Hasil Uji Mann Whitney Abnormal Return

\begin{tabular}{ccc}
\hline $\begin{array}{c}\text { Periode } \\
\text { Jendela }\end{array}$ & $\begin{array}{c}\text { Signifikansi } \\
\text { (2-tailed })\end{array}$ & $\begin{array}{c}\text { Keterangan } \\
\text { Abnormal Return }\end{array}$ \\
\hline $\mathrm{t}-3$ & 0,00 & Terdapat \\
$\mathrm{t}-2$ & 0,33 & Tidak Terdapat \\
$\mathrm{t}-1$ & 0,84 & Tidak Terdapat \\
$\mathrm{t} 0$ & 0,35 & Tidak Terdapat \\
$\mathrm{t}+1$ & 0,79 & Tidak Terdapat \\
$\mathrm{t}+2$ & 0,03 & Terdapat \\
$\mathrm{t}+3$ & 0,51 & Tidak Terdapat \\
\hline
\end{tabular}

Sumber: Data diolah, 2018

Apabila sig $(2$-tailed $) \leq 0,05$ maka terdapat perbedaan reaksi pasar yang signifikan antara perusahaan manufaktur dan non manufaktur begitu juga sebaliknya. Hasil pengujian abnormal return perusahaan manufaktur dan non 
manufaktur menunjukkan bahwa pada periode hari ketiga sebelum pengumuman dan hari kedua setelah pengumuman terdapat perbedaan reaksi pasar antara perusahaan manufaktur dan non manufaktur, hal ini ditunjukkan dari sig (2-tailed) $<0,05$ pada periode hari ketiga sebelum pengumuman dan hari kedua setelah pengumuman. Pada 2 hari sebelum pengumuman, pada saat pengumuman, hari pertama dan hari ketiga setelah pengumuman tidak terdapat perbedaan reaksi.

Penelitian menggunakan pendekatan event study, yaitu untuk mengetahui adanya reaksi pasar atas informasi yang diumumkan atau dipublikasikan. Penelitian ini menyatakan bahwa terdapat abnormal return yang signifikan pada hari ketiga sebelum pengumuman dan hari kedua setelah pengumuman. Perubahan rata-rata abnormal return perusahaan manufaktur dapat dilihat pada Gambar 2.

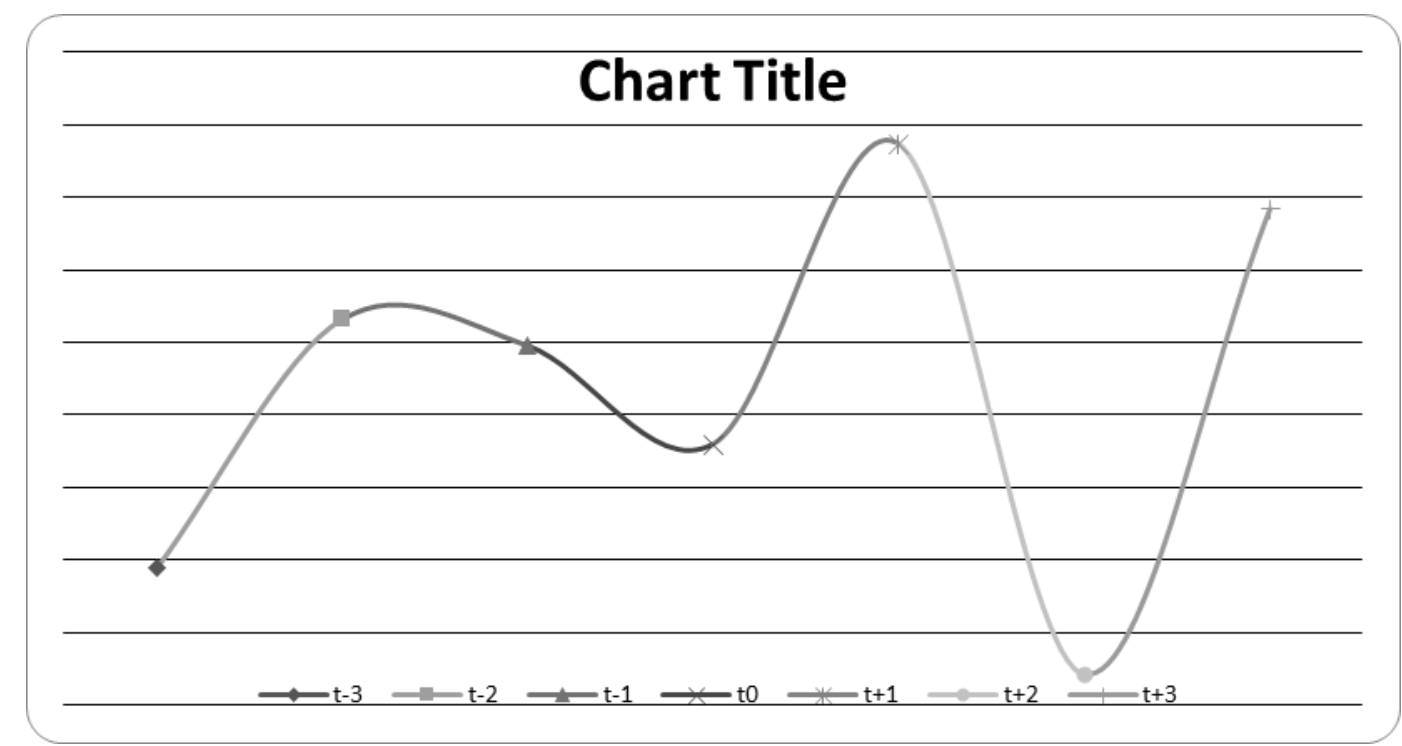

Gambar 2. Perubahan Rata-Rata abnormal return Saham Perusahaan Manufaktur Periode Pengamatan Penerbitan Perubahan Peraturan Kemenperin NOMOR 31/M-IND/PER/8/2017

Sumber: Data diolah, 2018 
Berdasarkan grafik di atas selama periode peristiwa, terdapat rata-rata abnormal return negatif pada periode 3 hari sebelum pengumuman, pada saat pengumuman, dan hari kedua setelah pengumuman. Rata-rata abnormal return negatif yang signifikan terjadi pada periode hari ketiga sebelum pengumuman dan hari kedua setelah pengumuman, sedangkan pada periode hari pertama setelah pengumuman dan hari ketiga setelah pengumuman terdapat rata-rata abnormal return positif yang tidak signifikan. Abnormal return negatif menunjukkan bahwa investor tidak menyukai perubahan peraturan tersebut. Dari hasil rata-rata abnormal return untuk masing-masing hari di periode peristiwa dapat ditarik kesimpulan bahwa; 1) terdapat reaksi pasar yang signifikan pada hari ketiga sebelum pengumuman dan hari kedua setelah pengumuman menunjukkan bahwa peristiwa tersebut mengandung informasi; 2) Adanya reaksi pasar yang signifikan pada hari ketiga sebelum pengumuman menunjukkan kemungkinan adanya sinyal dari pemerintah mengenai perubahan peraturan tersebut; dan 3) Pasar bereaksi lambat dan berkepanjangan untuk menyerap infomasi yang ditunjukkan pada masih adanya abnormal return hari kedua setelah pengumuman.

Adanya reaksi pasar yang signifikan pada hari kedua setelah pengumuman menunjukkan bahwa investor memerlukan waktu untuk mengidentifikasi perubahan peraturan tersebut. Isi dari perubahan peraturan tersebut adalah perubahan tentang Bea Masuk Umum/Most Favoured Nation (MFN), Dokumen perijinan dalam rangka larangan dan pembatasan impor/ekspor, Bea Keluar, Bea Masuk Free Trade Agreement (FTA), Pajak Dalam Rangka Impor (PPN, PPnBM dan PPh Pasal 22), BMAD (Bea Masuk Anti Dumping) dan BMTP (Bea Masuk 
Erving Anggiatma Napitupulu dan Gerianta Wirawan Yasa. Analisis...

Tindak Pengaman). Hal tersebut akan berpengaruh negatif terhadap laba/rugi perusahaan manufaktur.

Setelah mengetahui rata-rata abnormal return perusahaan manufaktur, maka selanjutnya adalah melihat rata-rata abnormal return perusahaan non manufaktur. Perubahan rata-rata abnormal return perusahaan non manufaktur dapat di lihat dari Gambar 3. Dari grafik yang tercantum pada Gambar 3 dapat terlihat terjadi rata-rata abnormal return positif yang tidak signifikan pada periode hari ketiga sebelum pengumuman, hari kedua sebelum pengumuman, hari pertama sebelum pengumuman, hari pertama setelah pengumuman, dan hari ketiga setelah pengumuman setelah pengumuman, hal ini menunjukan bahwa return realisasian lebih besar dibandingkan dengan return ekspektasian. Pada periode pada saat pengumuman dan hari kedua setelah pengumuman terjadi rata-rata abnormal return negatif yang tidak signifikan, hal ini menunjukan bahwa return realisasian lebih kecil dibandingkan dengan return ekspektasian. Dari hasil tersebut dapat disimpulkan bahwa perubahan peraturan tersebut tidak mempengaruhi reaksi investor terhadap perusahaan non manufaktur.

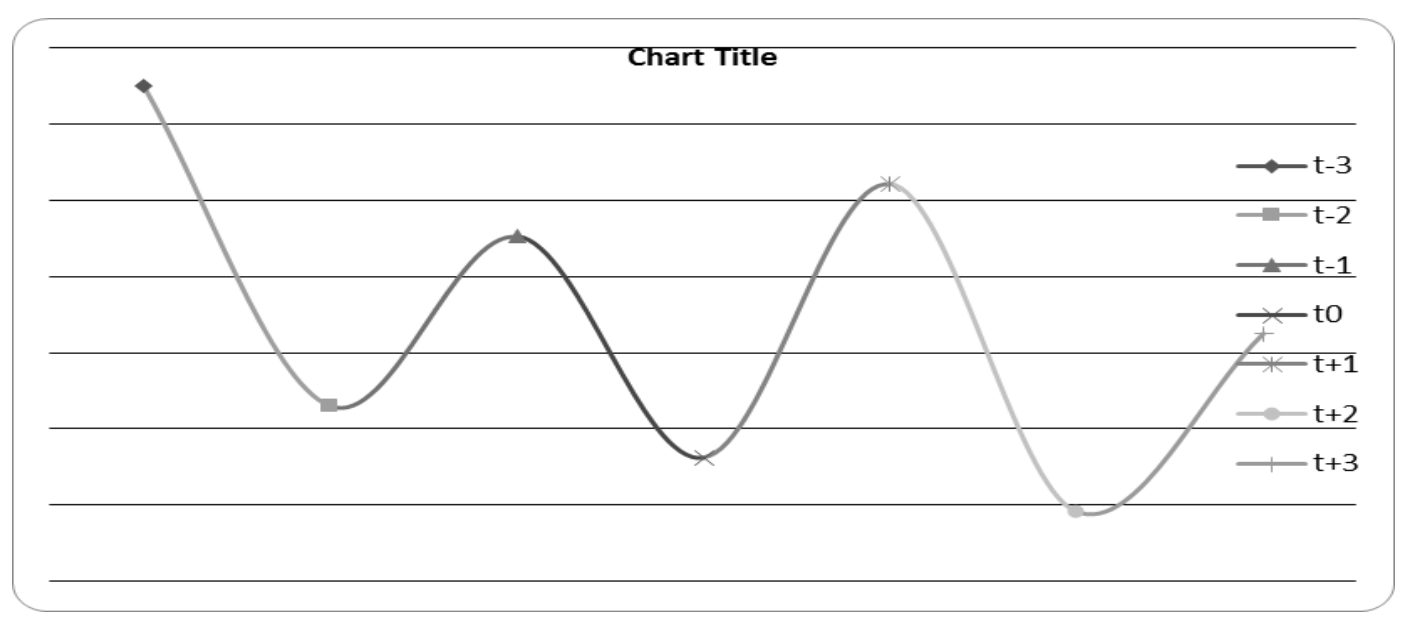


Gambar 3. Perubahan Rata-Rata abnormal return Saham Perusahaan Non Manufaktur Periode Pengamatan Penerbitan Perubahan Peraturan Kemenperin NOMOR 31/M-IND/PER/8/2017

Sumber: Data diolah, 2018

Investor selalu mencari informasi yang relevan dengan kondisi pasar modal untuk pengambilan keputusan investasi. Informasi yang tersebar tidak semua merupakan informasi yang berharga, akibatnya pelaku pasar modal harus secara tepat memilih informasi-informasi yang layak (relevan) untuk dijadikan pengambilan keputusan. Peristiwa penerbitan perubahan peraturan Kemenperin NOMOR 31/M-IND/PER/8/2017 menunjukkan adanya reaksi yang ditunjukkan dengan adanya abnormal return yang signifikan pada hari ketiga sebelum pengumuman dan hari kedua setelah pengumuman.

Adanya reaksi pasar tersebut berarti investor menganggap bahwa informasi dari pengumuman perubahan peraturan Kemenperin NOMOR 31/MIND/PER/8/2017 mengandung informasi.

\section{SIMPULAN}

Simpulan yang dapat diberikan berdasarkan hasil penelitian yang dilakukan yaitu Investor bereaksi negatif pada hari ketiga sebelum pengumuman perubahan peraturan dan hari kedua setelah pengumuman perubahan peraturan. Hal itu dapat dilihat dari abnormal return yang negatif. Adanya abnormal return pada hari ketiga sebelum pengumuman menunjukkan kemungkinan adanya sinyal dari pemerintah atas perubahan peraturan tersebut, sedangkan adanya abnormal return negatif pada saat hari kedua setelah pengumuman menunjukkan informasi tersebut merupakan informasi yang sulit dan memerlukan waktu identifikasi. Hasil menunjukkan bahwa terdapat perbedaan reaksi pasar perusahaan manufaktur dan 
perusahaan non manufaktur pada hari ketiga sebelum pengumuman dan hari kedua setelah pengumuman

Penelitian ini diharapkan dapat bermanfaat untuk investor, perusahaan, dan penelitian-penelitian selanjutnya. Berdasarkan simpulan yang ada, peneliti dapat memberikan saran yaitu untuk para investor dan calon investor yang ingin berinvestasi sebaiknya lebih mempertimbangkan dan menganalisis peristiwa serupa yang mungkin terjadi kedepannya sehingga para investor dan calon investor dapat mengambil keputusan investasi yang lebih baik dan dapat memeroleh keuntungan yang diinginkan.

Keterbatasan dalam penelitian ini adalah hanya menggunakan satu model estimasi, yaitu mean adjusted model sehingga hasil yang didapat tidak bisa dibandingkan dengan model lain. Peneliti selanjutnya sebaiknya menggunakan model estimasi selain mean adjusted model sehingga diperoleh hasil yang dapat diperbandingkan.

\section{REFERENSI}

Endah, Aprilia Fajari., \& Widanaputra A.A.G.P. (2016). "Reaksi Pasar Terhadap Larangan Peredaran MInuman Beralkohol”. E-jurnal Akuntansi Universtitas Udayana, 17 (1), hal 453-480.

Haryanto. (2011). "Reaksi Investor Terhadap Pengumuman Deviden Di Bursa Efek Indonesia”. Jurnal Keuangan dan Perbankan, 15 (2), Hal 213 - 220.

Putri, Uswatun Ari. (2017). “Analisis Reaksi Pasar Sebelum Dan Sesudah Terbitnya Peraturan Menteri Keuangan (PMK) Tax Amnesty terhadap Trading Volume Activity dan Abnormal Return (Event Study Pada Perusahaan Yang Terdaftar Dalam LQ 45 Di Bursa Efek Indonesia ”. Skripsi S-1 Universitas Lampung, Lampung.

Republik Indonesia. 2017. Peraturan Menteri Perindusrian Republik Indonesia NOMOR 31/M-IND/PER/8/2017 Tentang Perubahan Ketiga Atas Peraturan Menteri Perindustrian NOMOR 19/M-IND/PER/2/2010 Tentang Daftar 
Mesin, Barang, Dan Bahan Produksi Dalam Negeri Untuk Pembangunan Atau Pengembangan Industri Dalam Rangka Penanaman Modal. Menteri Perindustrian Republik Indonesia.

Undang-Undang Republik Indonesia Nomor 12 Tahun 2011 tentang Pembentukan Peraturan Perundang-undangan.

Utami, Sari. (2015). "Reaksi Pasar Dan Peningkatan Likuiditas Terhadap Kebijakan Perubahan Fraksi Harga Saham (Perbandingan Perusahaan LQ45 Dengan Perusahaan JII)". Tesis S-2 Universitas Islam Indonesia, Yogyakarta.

Wibowo, Agung. (2017). "Reaksi Investor Pasar Modal Indonesia Terhadap Paket kebijakan Ekonomi Tahap I Jokowi - JK". Jurnal Media Ekonomi Dan Manajemen, 32 (1), hal. 1 - 13.

Yusuf, Sri Dewi. (2009). “Analisis Reaksi Investor Terhadap Pengumuman Right Issue Di Bursa Efek Jakarta (Suatu Pengamatan pada Return, Abnormal Return, Aktivitas Volume Perdagangan dan Bid-Ask Spread Saham)". Jurnal WACANA, 12 (4), hal. 1 - 23. 